\title{
Yield of Margaret Queen radish hybrid according to the spacing
}

\author{
Marlei Rosa dos Santos ${ }^{1}$, Romário da Silva Moreira ${ }^{1}$, Tadeu Barbosa Martins Silva ${ }^{1}$, Ronildo \\ Almeida de Sousa ${ }^{1}$, Rubenalto da Silva Almeida ${ }^{1}$, Laércio Gomes Carreiro ${ }^{1}$
}

\author{
${ }^{1}$ Universidade Estadual do Piauí, Campus Cerrado do Alto Parnaíba, Uruçuí, Piauí, Brasil. E-mail: marleirs@ yahoo.com.br, \\ romariomoreira524@gmail.com, silvatbm@yahoo.com.br, ronildoalmeida@hotmail.com, rubenaltosilva@ hotmail.com, \\ laercio_gc@outlook.com
}

Received: 12/02/2020; Accepted: 15/06/2020.

\begin{abstract}
Currently, some important hybrids have replaced traditional radish cultivars, without, however, developing necessary studies on the best planting density for different Brazilian conditions. Thus, the present study aimed to evaluate the effect of spacing between rows and plants on the development and yield of the 'Margaret Queen' radish hybrid. A randomized blocks experimental design with four replications in a $3 \times 3$ factorial scheme was used. Three row spacings $(10,15$, and $20 \mathrm{~cm})$ and three spacings between plants in the row $(3,6$, and $9 \mathrm{~cm})$ were evaluated. The seeds were sown in furrows at $1.0 \mathrm{~cm}$ deep, and the harvest was carried out at 28 days after sowing. The following were determined: number of leaves, root diameter, root length, average root weight, non-damaged root yield, damaged root yield, commercial root yield, and non-commercial root yield. The row spacing did not influence the development of the plants, but it affected the root yield. The row spacing of $20 \mathrm{~cm}$ had the lowest root yield. The spacings that provided the highest commercial root yield (D>30 mm) of the Margaret Queen radish hybrid were 10 and $15 \mathrm{~cm}$ between rows and $6 \mathrm{~cm}$ between plants. The $3 \mathrm{~cm}$ spacing between plants is the least suitable for the cultivation of the Margaret Queen radish hybrid radish under the studied conditions.
\end{abstract}

Keywords: Raphanus sativus, plant development, planting density, commercial roots.

\section{Produtividade de rabanete híbrido Margaret Queen em função do espaçamento}

\section{RESUMO}

Atualmente, alguns híbridos importantes têm substituído as tradicionais cultivares de rabanete, sem, no entanto, desenvolver estudos básicos sobre a melhor densidade de plantio para as diversas condições brasileiras. Assim, o presente trabalho teve como objetivo avaliar o efeito do espaçamento entre linhas e plantas no desenvolvimento e produtividade do rabanete híbrido 'Margaret Queen'. O delineamento experimental utilizado foi em blocos casualizados, com quatro repetições, no esquema fatorial 3 x 3, sendo três espaçamentos entre linhas (10, 15 e 20 $\mathrm{cm})$ e três espaçamentos entre plantas $(3,6$ e $9 \mathrm{~cm})$. As sementes foram semeadas em sulcos a um centímetro de profundidade e a colheita foi realizada aos 28 dias após a semeadura. Foram determinados: número de folhas, diâmetro e comprimento da raiz, peso médio de raiz, produtividade total de raiz sem defeito e de raízes danificadas, produtividade de raízes comerciais e raízes não comerciais. O espaçamento entre linhas não influenciou o desenvolvimento das plantas, mas influenciou a produtividade de raízes, que foi menor no espaçamento de $20 \mathrm{~cm}$ entre linhas. Os espaçamentos que proporcionaram maior produtividade de raízes comerciais (D>30 mm) do híbrido Margaret Queen foram de 10 e $15 \mathrm{~cm}$ entre linhas e de $6 \mathrm{~cm}$ entre plantas. O espaçamento de $3 \mathrm{~cm}$ entre plantas é o menos indicado para a cultura do rabanete híbrido Margaret Queen, nas condições estudadas.

Palavras-chave: Raphanus sativus, desenvolvimento de plantas, densidade de plantio, raízes comerciais. 


\section{Introduction}

The radish (Raphanus sativus L.), belonging to the Brassicaceae family, having its origin in the Mediterranean regions, is an annual crop of small size and fast development, presenting itself as an essential alternative for vegetable producers (Steiner et al., 2009). From the main root, an edible bulb with a reddish external color, white pulp, and a spicy flavor develops (Maia et al., 2011). It is an essential species from an economical and nutritional point of view, as it has significant antioxidant activity, but little contemplated by the research, mainly about the crop treatments (Camargo et al., 2007; Silva et al., 2012).

Among the factors that most influence the yield of different crops is the number of plants per area (Aquino et al., 2005). In optimizing production, one of the factors to be considered is the ideal spacing, since a higher number of plants per area provides greater productivity. However, at higher planting density, the pressures exerted by the plant population affect their development (Resende and Costa, 2003). This factor promotes competition between individuals of the same and different species for growth resources, such as water, light, and nutrients; it can affect production, resulting in the formation of smaller productive units, that is, thinner roots (Janick, 1986; Lopes et al., 2008; Corrêa et al., 2014). The appropriate is the establishment of the optimal population, which maximizes the exploitation of these factors, ensuring higher productivity (Baier et al., 2009).

Minami et al. (1998) stated that to optimize the radish production, the ideal spacing that provides good growth accompanied by high root yield must be established since the spacing relationship between plants and between lines directly impacts the crop's ecophysiological potential. However, changes in spacing and density induce a series of changes in the plant growth and development that need to be known and studied (Freitas et al., 2009).

According to Amorim et al. (2014), the best spacing to produce commercial radish roots is $10 \mathrm{~cm}$ between rows and $5 \mathrm{~cm}$ between plants. On the other hand, Minami et al. (1998), studying the effect of different spacing between rows $(15,20$, and $25 \mathrm{~cm})$ and between plants $(5$ and $10 \mathrm{~cm})$ on the radish crop, they reported that the different spacing between rows did not affect the variables evaluated (number of leaves, root and leaf production $(\mathrm{g})$ per plot, average root and leaf production per plant, and the relationship between root and leaf production). They observed an increase in root production per plant using $10 \mathrm{~cm}$ spacing between plants.

In some regions of Brazil, vegetable producers have no tradition in the cultivation of radish, so few works have been developed on the crop, with a lack of information on its cultivation, spacing, production, and development, especially in Uruçuí-PI. With the migration of people from the south of Brazil to the south of Piauí, there is a need for more information about the performance of this crop to meet the new local demand. Thus, the present study aimed to evaluate the effect of spacing between rows and plants on the development and yield of the Margaret Queen radish hybrid.

\section{Material and Methods}

The experiment was conducted in the experimental area of the State University of Piauí - UESPI, Campus of Cerrados do Alto Parnaíba, Uruçuí- PI, at the southern region of the state, at $07^{\circ} 13^{\prime} 46^{\prime \prime} \mathrm{S}, 44^{\circ} 33^{\prime} 22^{\prime} \mathrm{W}$, and altitude of $167 \mathrm{~m}$. The maximum and minimum temperature and relative air humidity data during the period of experiment conduction are shown in Figure 1. During the period, there was no precipitation (INMET, 2018). A randomized blocks experimental design with four replications in a $3 \times 3$ factorial scheme was used. Three row spacings $(10,15$, and $20 \mathrm{~cm})$ and three spacings between plants in the row $(3,6$, and $9 \mathrm{~cm})$ were evaluated.

Before sowing, the soil sample was taken in the 0 - 20 cm layer, which was sent to the laboratory; the results are shown in Table 1. Based on the need of radish cultivation (Vidigal and Pedrosa, 2007) and the results of soil analysis, the need for fertilization was calculated. It was applied $30 \mathrm{~g} \mathrm{~m}^{-2}$ of the NPK formulation (10:10:10), 10 $\mathrm{g} \mathrm{m}^{-2}$ of potassium chloride, and $33 \mathrm{~g} \mathrm{~m}^{-2}$ of simple superphosphate. It was also used $4.5 \mathrm{~kg} \mathrm{~m}^{-2}$ of cattle manure, uniformly distributed, and incorporated into the soil the day before sowing. According to the results of soil analysis (Table 1), it was not necessary to apply lime to correct the $\mathrm{pH}$, which was 6.7.

Margaret Queen radish hybrid seeds, more adapted to the climatic conditions of the region, were used (Moreira et al., 2019). Sowing was carried out on July $15^{\text {th }}, 2018$, in furrows $1.0 \mathrm{~cm}$ deep, with row spacing according to the treatments mentioned earlier. After germination and establishment of the plants, when they were $5 \mathrm{~cm}$ high, thinning was carried out, adjusting the spacing between plants in the line, according to the treatments $(3,6$, and 9 $\mathrm{cm})$. Watering was carried out daily, using a watering can. Weed control was performed whenever necessary.

The harvest was carried out 28 days after sowing, according to the cycle of the hybrid used (Vidigal and Pedrosa, 2019). The useful plot of $0.25 \mathrm{~m} 2$ was harvested in the central area of the seedbed. After harvesting, the plants were washed to remove soil residue from the roots. Subsequently, the number of leaves was evaluated in 20 plants randomly chose. Also, root diameter ( $\mathrm{mm})$, root length $(\mathrm{mm})$, average root weight $(\mathrm{g})$, non-damaged root yield $\left(\mathrm{t} \mathrm{ha}^{-1}\right)$, damaged root yield (cracked, deformed, undeveloped) $\left(\mathrm{t} \mathrm{ha}^{-1}\right)$, and commercial root yield $\left(\mathrm{t} \mathrm{ha}^{-1}\right)$ 
were evaluated. Commercial roots were those with a diameter greater than $30 \mathrm{~mm}$ (Castro et al., 2016) and non-commercial were those with a diameter of less than $30 \mathrm{~mm}$.

The data were subjected to analysis of variance, and the comparisons of the means were performed by the Tukey test, at $5 \%$ probability, using the SISVAR software, version 5.6 (Ferreira, 2010).

\section{Results and Discussion}

Significant effect of spacing between plants (SP) $(\mathrm{P}<0.01)$ and not significant of row spacing $(\mathrm{RS})$, and interaction between SP and RS (P>0.05) on the number of leaves per plant, root diameter, and root length was observed, with average values of $5.57 ; 30.64 \mathrm{~mm}$ and $37.35 \mathrm{~mm}$, respectively (Table 2).

In this study, it was observed that the spacing between plants influenced the number of leaves per plant. The spacing between plants of $3 \mathrm{~cm}$ provided the lowest number of leaves per plant (5.33), and the spacings of 6 and $9 \mathrm{~cm}$ resulted in 5.67 and 5.72 leaves per plant (Table 2). These results are similar to those found by Moreira et al. (2019), in which they evaluated six radish cultivars, in Uruçuí-PI, at the $15 \times 5 \mathrm{~cm}$ spacing. There was a tendency to increase the number of leaves with greater spacing between plants. These results are due to the smaller number of plants per area, allowing higher and better development of plants. According to Linhares et al. (2010), the number of leaves is important, considering that this organ is responsible for the photosynthetic process, which in turn, is responsible for the production of photoassimilates that will be sent to the productive organs of the plant. The number of leaves is directly linked to the levels of nutrients available in the soil and mainly to the morphological characteristics of each cultivar and may also range according to the growing season (Bonela et al., 2017).

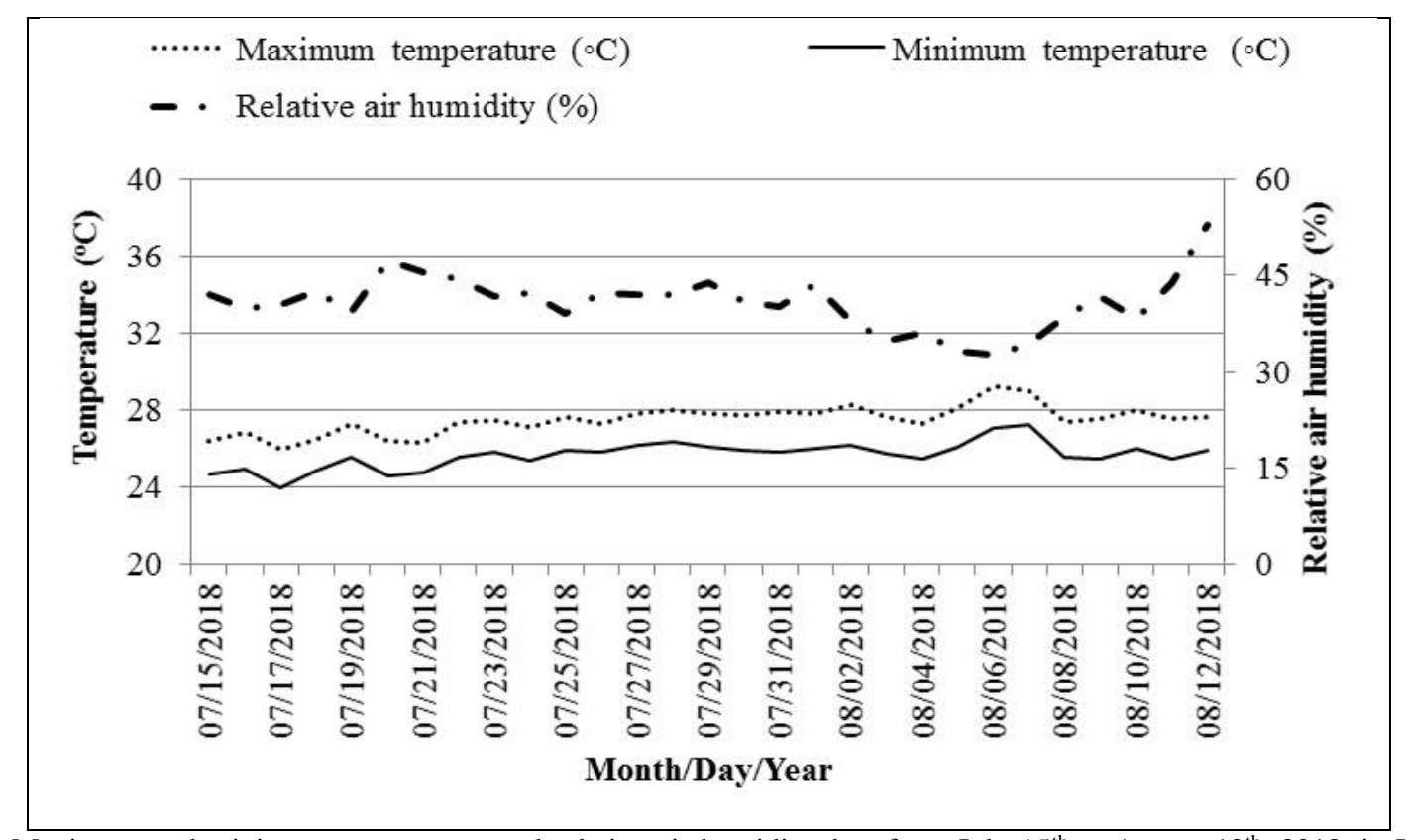

Figure 1. Maximum and minimum temperature and relative air humidity data from July $15^{\text {th }}$ to August $12^{\text {th }}$, 2018, in Uruçuí- PI, UESPI, 2018. Source: INMET, 2018.

Table 1. Results of soil chemical analysis at the 0-20 cm soil layer. Uruçuí - PI, UESPI, 2018

\begin{tabular}{|c|c|c|c|}
\hline Properties & Results & Properties & Results \\
\hline $\mathrm{pH}\left(\mathrm{H}_{2} \mathrm{O}\right)$ & 6.70 & Base saturation (\%) & 94.90 \\
\hline Organic matter $\left(\mathrm{g} \mathrm{kg}^{-1}\right)$ & 15.50 & $\mathrm{Al}$ saturation $(\%)$ & 0.00 \\
\hline $\mathrm{P}\left(\mathrm{mg} \mathrm{dm}^{-3}\right)$ & 109.80 & $\mathrm{Ca}(\%)$ & 79.90 \\
\hline $\mathrm{K}^{+}\left(\mathrm{mg} \mathrm{dm}^{-3}\right)$ & 113.38 & $\operatorname{Mg}(\%)$ & 11.80 \\
\hline $\mathrm{Ca}^{+2}\left(\mathrm{cmol}_{\mathrm{c}} \mathrm{dm}^{-3}\right)$ & 7.19 & $\mathrm{~K}(\%)$ & 3.20 \\
\hline $\mathrm{Mg}^{+2}\left(\mathrm{cmol}_{\mathrm{c}} \mathrm{dm}^{-3}\right)$ & 1.06 & $\mathrm{~S}\left(\mathrm{mg} \mathrm{dm}^{-3}\right)$ & 0.98 \\
\hline $\mathrm{Al}^{+3}\left(\mathrm{cmol}_{\mathrm{c}} \mathrm{dm}^{-3}\right)$ & 0.00 & $\mathrm{Fe}\left(\mathrm{mg} \mathrm{dm}^{-3}\right)$ & 21.59 \\
\hline $\mathrm{H}^{+}+\mathrm{Al}^{+3}\left(\mathrm{cmol}_{\mathrm{c}} \mathrm{dm}^{-3}\right)$ & 0.46 & $\operatorname{Mn}\left(\mathrm{mg} \mathrm{dm}^{-3}\right)$ & 39.90 \\
\hline $\mathrm{SB}\left(\mathrm{cmol}_{\mathrm{c}} \mathrm{dm}^{-3}\right)$ & 8.54 & $\mathrm{Cu}\left(\mathrm{mg} \mathrm{dm}^{-3}\right)$ & 0.70 \\
\hline $\operatorname{CEC}\left(\mathrm{cmol}_{\mathrm{c}} \mathrm{dm}^{-3}\right)$ & 9.00 & $\mathrm{Zn}\left(\mathrm{mg} \mathrm{dm}^{-3}\right)$ & 9.70 \\
\hline
\end{tabular}

P, K, Cu, Fe, Zn e Mn: Mehlich-l Extractor; Al, Ca, Mg: KCL Extractor $1 \mathrm{~mol} / \mathrm{L} ; \mathrm{S}\left(\mathrm{Ca}\left(\mathrm{H}_{2} \mathrm{PO}_{4}\right) 20.01 \mathrm{~mol} / \mathrm{L} ; \mathrm{SB}=\mathrm{Ca}^{+2}+\mathrm{Mg}^{+2}+\mathrm{K}^{+}+\right.$ $\mathrm{Na}^{+} ; \mathrm{H}^{+}+\mathrm{Al}^{+3}$ : Calcium Acetate $0.5 \mathrm{M}$ Extractor, $\mathrm{pH}$ 7.0; $\mathrm{CEC}=\mathrm{SB}+\mathrm{H}^{+}+\mathrm{Al}^{+3}$; Organic matter: Walkley-Black chromic acid wet oxidation method. 
Table 2. Number of leaves per plant, root diameter, and root length of Margaret Queen radish hybrid grown in different spacing between rows and plants. Uruçuí-PI, UESPI, 2018.

\begin{tabular}{|c|c|c|c|}
\hline Row spacing & Number of leaves per plant & Root diameter & Root length \\
\hline & $\mathrm{n}^{\mathrm{o}}$ & \multicolumn{2}{|c|}{-------------- mm -------------- } \\
\hline $10 \mathrm{~cm}$ & $5.53 \mathrm{a}$ & $29.53 \mathrm{a}$ & $36.65 \mathrm{a}$ \\
\hline $15 \mathrm{~cm}$ & $5.62 \mathrm{a}$ & $30.79 \mathrm{a}$ & $37.32 \mathrm{a}$ \\
\hline $20 \mathrm{~cm}$ & $5.57 \mathrm{a}$ & $31.61 \mathrm{a}$ & $38.08 \mathrm{a}$ \\
\hline \multirow[t]{2}{*}{ Spacing between plants } & Number of leaves per plant & Root diameter & Root length \\
\hline & $\mathrm{n}^{\mathrm{o}}$ & \multicolumn{2}{|c|}{-------------- mm --------------- } \\
\hline $3 \mathrm{~cm}$ & $5.33 \mathrm{~b}$ & $28.42 \mathrm{~b}$ & $33.74 \mathrm{~b}$ \\
\hline $6 \mathrm{~cm}$ & $5.67 \mathrm{a}$ & $31.55 \mathrm{a}$ & $38.94 \mathrm{a}$ \\
\hline $9 \mathrm{~cm}$ & $5.72 \mathrm{a}$ & $31.96 \mathrm{a}$ & $39.38 \mathrm{a}$ \\
\hline Overall mean & 5.57 & 30.64 & 37.35 \\
\hline $\mathrm{CV}(\%)$ & 4.91 & 8.50 & 9.89 \\
\hline Block & 0.2783 & 6.7508 & 155.5301 \\
\hline Row spacing (RS) & $0.0230^{\mathrm{ns}}$ & $13.2295^{\mathrm{ns}}$ & $6.1218^{\mathrm{ns}}$ \\
\hline Spacing between plants (SP) & $0.5621 * *$ & $44.8903 * *$ & $118.1517 * *$ \\
\hline RS x SP & $0.0343^{\mathrm{ns}}$ & $2.2276^{\mathrm{ns}}$ & $4.5394^{\mathrm{ns}}$ \\
\hline Error & 0.0748 & 6.7823 & 13.6346 \\
\hline
\end{tabular}

** Significant at $1 \%$ probability by the $\mathrm{F}$ test. ${ }^{\mathrm{ns}}$ not significant at $5 \%$ probability by the $\mathrm{F}$ test.

Averages followed by the same lowercase letter in the column do not differ by the Tukey test at $5 \%$ probability.

Regarding the diameter and length of roots, the spacings between plants of 6 and $9 \mathrm{~cm}$ showed the highest averages, and they did not differ statistically from each other, with 31.55 and $31.96 \mathrm{~mm}$ diameter, and 38.94 and $39.38 \mathrm{~mm}$ length, respectively (Table 2). The $3 \mathrm{~cm}$ spacing between plants, on the other hand, obtained the lowest mean of diameter and length of roots, with 28.42 and $33.74 \mathrm{~mm}$, respectively; values higher than that found by Moreira et al. (2019), who observed values of $25.17 \mathrm{~mm}$ diameter and $29.28 \mathrm{~mm}$ length in the Margaret Queen hybrid, grown at $15 \times 5 \mathrm{~cm}$ spacing. Minami et al. (1998), studying radish yield related to population density and spacing, observed higher development of shoot and roots in the highest spacings between rows and plants.

In the study developed by Corrêa et al. (2014), the reduction in root size associated with increased plant density must have occurred due to the competition between plants for light and nutrients. At higher plant densities, there is a reduction in the availability of nutrients for each plant, which may be a factor that contributes to the decrease in plant development. The high number of plants results in less photosynthetic radiation for the lower leaves, resulting in higher shading and a reduction in the net photosynthetic rate per plant, resulting in the formation of thinner roots (Lopes et al., 2008).

Salgado et al. (2006) found a radish root diameter of $36 \mathrm{~mm}$ in the cv. Hybrid No. 19 under organic management in an environment with an average annual temperature of $23{ }^{\circ} \mathrm{C}$. The temperature may have been one of the limiting factors of the diameter. According to Costa et al. (2006), variations in humidity and temperature of the soil during the development of plants can impair the yield and quality of roots. However, for fresh consumption, the Brazilian market prefers cylindrical-shaped roots, with an average diameter of 30 $\mathrm{mm}$ (Linhares et al., 2010). However, there are places with less demanding consumers, and roots up to $20 \mathrm{~mm}$ diameter can be commercialized.

Regarding the average root weight and damaged root yield, there was a significant effect of SP and not significant of RS and interaction between SP and RS, with average values of $15.74 \mathrm{~g}$ and $1.19 \mathrm{t}$ ha-1, respectively (Table 3 ). The average root weight found was higher than that observed by Moreira et al. (2019) $(13.03 \mathrm{~g})$. There was a significant effect of RS $(\mathrm{P}<0.01)$ and SP $(\mathrm{P}<0.05)$, and no significant impact $(\mathrm{P}>0.05)$ of interaction between the factors on the non-damaged root yield.

The $3 \mathrm{~cm}$ spacing between plants had the lowest average root weight $(10.98 \mathrm{~g})$, and the 6 and $9 \mathrm{~cm}$ spacings showed the highest average root weight (16.67 and $19.59 \mathrm{~g}$ ), respectively (Table 3 ). Similar results were found by Weston (1982) and Minami et al. (1998), where they observed that greater spacing between plants produced larger roots and, consequently, with higher weight. The good development of the roots can be attributed to the content of organic matter (OM) and to the characteristics of the soil where it was cultivated, as it had a medium texture and $15.5 \mathrm{~g} \mathrm{~kg}^{-1}$ of organic matter (Table 1). The growth and development of radish roots are related to the soil organic matter content and, mainly, to the physical characteristics and clay content, which directly influence porosity, providing better yields (Bonela et al., 2017).

The row spacing of 10 and $15 \mathrm{~cm}$ showed the highest values of non-damaged root yield, with $14.56 \mathrm{t} \mathrm{ha}^{-1}$ and 
$14.42 \mathrm{t} \mathrm{ha}^{-1}$, respectively (Table 3 ), and the row spacing of $20 \mathrm{~cm}$ had a value of non-damaged root yield of 10.55 $\mathrm{t} \mathrm{ha}^{-1}$, with around $4.0 \mathrm{t} \mathrm{ha}^{-1}$ less. The spacing of $3 \mathrm{~cm}$ between plants had the highest non-damaged root yield, with $15.22 \mathrm{t} \mathrm{ha}^{-1}$. However, it did not differ statistically from the non-damaged root yield achieved in the spacing of $6 \mathrm{~cm}$ between plants, with $13.17 \mathrm{t} \mathrm{ha}^{-1}$, which, in turn, also did not differ from non-damaged root yield obtained by the spacing of $9 \mathrm{~cm}$ between plants, with $11.15 \mathrm{t} \mathrm{ha}^{-1}$ (Table 3). The highest yield in the shortest spacing between plants is probably due to the larger number of plants per area, a result similar to that found by Lemos Neto et al. (2018). They also observed the highest yield in the shortest spacing between plants $(0.5 \mathrm{~cm})$. Minami et al. (1998) found different results, noting that the total root yield was not significantly affected by the spacing between rows and plants. Despite the increase of nondamaged root yield with the reduction of spacing between plants, the lower the spacing between plants and rows, the lower the average root weight (Table 3 ).

There was no difference in the damaged root yield (cracked, deformed, undeveloped) in the different row spacings, with an average yield of $1.19 \mathrm{t} \mathrm{ha}^{-1}$ (Table 3). The spacing of $3 \mathrm{~cm}$ between plants provided the highest damaged root yield $\left(1.64 \mathrm{t} \mathrm{ha}^{-1}\right)$ and the spacing of $9 \mathrm{~cm}$ the lowest $\left(0.68 \mathrm{t} \mathrm{ha}^{-1}\right)$. The spacing of $6 \mathrm{~cm}$ was intermediate, not differing from the other two spacing between plants. These results are similar to the nondamaged root yield. The lowest damaged root yield in the spacing of $9 \mathrm{~cm}$ between plants was probably due to the smallest population of plants, which provided the lowest root yield, and each plant had more area to explore and benefit from nutrients, water, light, etc.

The analysis of variance of the commercial root yield, with a diameter $\geq 30 \mathrm{~mm}$, according to the classification recommended by Linhares et al. (2010), it was observed that there was no significant effect of the spacing between rows and plants and the interaction between them $(\mathrm{P}>0.05)$. However, when comparing the means by the Tukey test, the difference between the spacing of 3 and $6 \mathrm{~cm}$ between plants was observed in the row spacing of $10 \mathrm{~cm}$. In the row spacing of $6 \mathrm{~cm}$, there was the highest commercial root yield $\left(11.45 \mathrm{t} \mathrm{ha}^{-1}\right)$, however not differing from the commercial root yield obtained in the spacing of $9 \mathrm{~cm}$ between plants, $7.34 \mathrm{t} \mathrm{ha}^{-1}$ (Table 4). These values are below the crop potential and close to those found (11.12 $\mathrm{t} \mathrm{ha}^{-1}$ ) by Moreira et al. (2019), evaluating the Margaret Queen radish hybrid in the Uruçuí-PI region. According to Vidigal and Pedrosa (2019), radish can produce from 15 to $30 \mathrm{t} \mathrm{ha}^{-1}$, depending on the cultivar or hybrid and growing season. There was no difference between the row spacings (10, 15 , and $20 \mathrm{~cm})$ in the commercial root yield $(\mathrm{D} \geq 30 \mathrm{~mm})$ in the different spacing between plants $(3,6$, and $9 \mathrm{~cm})$.

The arrangement with $3 \mathrm{~cm}$ between plants and $10 \mathrm{~cm}$ between rows provided the lowest commercial root yield, with $3.97 \mathrm{t} \mathrm{ha}^{-1}$ (Table 4), these spacings are the less suitable for the growth of Margaret Queen radish hybrid. The lowest commercial root yield in the smallest spacing is in line with the statements of Janick (1986), with the increase in plant density per hectare, there is an increase of competition for essential growth factors such as nutrients, light, and water, generating a drop in crop yield.

There was a significant effect on the spacing between plants and rows $(\mathrm{P}<0.01)$ on the non-commercial root yield $(\mathrm{D}<30 \mathrm{~mm})$. There was no influence of the interaction between the factors on the non-commercial root yield $(\mathrm{P}>0.05)$. It was observed that the row spacing of $20 \mathrm{~cm}$ provided the lowest non-commercial root yield (6.34 $\mathrm{t}$ ha-1) within the spacing of $3 \mathrm{~cm}$ between plants. The row spacing of 10 and $15 \mathrm{~cm}$ showed the highest non-commercial root yield, 10.66 and $11.03 \mathrm{t} \mathrm{ha}^{-1}$, respectively (Table 5).

Table 3. Average root weight, non-damaged root yield (NDRY), and damaged root yield (cracked, deformed, and undeveloped) of Margaret Queen radish hybrid grown in different spacing between rows and plants. Uruçuí-PI, UESPI, 2018.

\begin{tabular}{|c|c|c|c|}
\hline Row spacing & Average root weight & Non-damaged root yield & Damaged root yield \\
\hline & $\mathrm{g}$ & \multicolumn{2}{|c|}{-------------- t ha ${ }^{-1}$} \\
\hline $10 \mathrm{~cm}$ & $14.51 \mathrm{a}$ & $14.56 \mathrm{a}$ & $1.38 \mathrm{a}$ \\
\hline $15 \mathrm{~cm}$ & $15.74 \mathrm{a}$ & $14.42 \mathrm{a}$ & $1.03 \mathrm{a}$ \\
\hline $20 \mathrm{~cm}$ & $16.98 \mathrm{a}$ & $10.55 \mathrm{~b}$ & $1.15 \mathrm{a}$ \\
\hline \multirow[t]{2}{*}{ Spacing between plants } & Average root weight & Non-damaged root yield & Damaged root yield \\
\hline & $\mathrm{g}$ & \multicolumn{2}{|c|}{--o-------- t ha $^{-1}$} \\
\hline $3 \mathrm{~cm}$ & $10.98 \mathrm{~b}$ & $15.22 \mathrm{a}$ & $1.64 \mathrm{a}$ \\
\hline $6 \mathrm{~cm}$ & $16.67 \mathrm{a}$ & $13.17 \mathrm{ab}$ & $1.24 \mathrm{ab}$ \\
\hline $9 \mathrm{~cm}$ & $19.59 \mathrm{a}$ & $11.15 \mathrm{~b}$ & $0.68 \mathrm{~b}$ \\
\hline Overall mean & 15.74 & 13.18 & 1.19 \\
\hline CV $(\%)$ & 21.01 & 22.58 & 15.14 \\
\hline Block & 24.7785 & 22.1814 & 0.4505 \\
\hline Row spacing $(\mathrm{RS})$ & $18.2287^{\mathrm{ns}}$ & $62.2196 * *$ & $0.3823^{\mathrm{ns}}$ \\
\hline Spacing between plants (SP) & $230.1062 * *$ & $49.7561 *$ & $2.7883 * *$ \\
\hline RS x SP & $5.4057^{\mathrm{ns}}$ & $17.6472^{\mathrm{ns}}$ & $0.4054^{\mathrm{ns}}$ \\
\hline Error & 10.9405 & 8.8552 & 0.4608 \\
\hline
\end{tabular}

** and * Significant at 1 and 5\% probability by the $\mathrm{F}$ test, respectively. ${ }^{\mathrm{ns}}$ not significant at $5 \%$ probability by the $\mathrm{F}$ test.

Averages followed by the same lowercase letter in the column do not differ by the Tukey test at $5 \%$ probability. 
Table 4. Commercial root yield $\left(\mathrm{t} \mathrm{ha}^{-1}\right)$ of Margaret Queen radish hybrid grown in different spacing between rows and plants. UruçuíPI, UESPI, 2018.

\begin{tabular}{|c|c|c|c|}
\hline \multirow{3}{*}{ Row spacing } & \multicolumn{3}{|c|}{ Commercial root yield $\left(\mathrm{t} \mathrm{ha}^{-1}\right)$} \\
\hline & \multicolumn{3}{|c|}{ Spacing between plants } \\
\hline & $3 \mathrm{~cm}$ & $6 \mathrm{~cm}$ & $9 \mathrm{~cm}$ \\
\hline $10 \mathrm{~cm}$ & $3.97 \mathrm{aB}$ & $11.45 \mathrm{aA}$ & $7.34 \mathrm{aAB}$ \\
\hline $15 \mathrm{~cm}$ & $7.25 \mathrm{aA}$ & $9.01 \mathrm{aA}$ & $8.61 \mathrm{aA}$ \\
\hline $20 \mathrm{~cm}$ & $6.42 \mathrm{aA}$ & $6.76 \mathrm{aA}$ & $6.84 \mathrm{aA}$ \\
\hline Overall mean & \multicolumn{3}{|c|}{7.52} \\
\hline $\mathrm{CV}(\%)$ & \multicolumn{3}{|c|}{54.39} \\
\hline Block & \multicolumn{3}{|c|}{21.1341} \\
\hline Row spacing (RS) & \multicolumn{3}{|c|}{$7.8618^{\mathrm{ns}}$} \\
\hline Spacing between plants (SP) & \multicolumn{3}{|c|}{$30.6007^{\mathrm{ns}}$} \\
\hline $\mathrm{RS} \times \mathrm{SP}$ & \multicolumn{3}{|c|}{$14.5555^{\mathrm{ns}}$} \\
\hline Error & \multicolumn{3}{|c|}{16.7081} \\
\hline
\end{tabular}

${ }^{\mathrm{ns}}$ not significant at $5 \%$ probability by the $\mathrm{F}$ test.

Means followed by the same lowercase letter in the column and uppercase letter in the row do not differ by Tukey test, at $5 \%$ probability.

Table 5. Non-commercial root yield $\left(\mathrm{t} \mathrm{ha}^{-1}\right)$ of Margaret Queen radish hybrid grown in different spacing between rows and plants. Uruçuí-PI, UESPI, 2018.

\begin{tabular}{|c|c|c|c|}
\hline \multirow{3}{*}{ Row spacing } & \multicolumn{3}{|c|}{ Non-commercial root yield $\left(\mathrm{t} \mathrm{ha}^{-1}\right)$} \\
\hline & \multicolumn{3}{|c|}{ Spacing between plants } \\
\hline & $3 \mathrm{~cm}$ & $6 \mathrm{~cm}$ & $9 \mathrm{~cm}$ \\
\hline $10 \mathrm{~cm}$ & $10.66 \mathrm{aA}$ & $5.51 \mathrm{aB}$ & $4.77 \mathrm{aB}$ \\
\hline $15 \mathrm{~cm}$ & $11.03 \mathrm{aA}$ & $4.25 \mathrm{aB}$ & $3.13 \mathrm{abB}$ \\
\hline $20 \mathrm{~cm}$ & $6.34 \mathrm{aA}$ & $2.55 \mathrm{bB}$ & $2.76 \mathrm{bB}$ \\
\hline Overall mean & & 5.67 & \\
\hline $\mathrm{CV}(\%)$ & & 35.13 & \\
\hline Block & & 0.9532 & \\
\hline Row spacing $(\mathrm{RS})$ & & $30.8012 * *$ & \\
\hline Spacing between plants (SP) & & $122.4581 * *$ & \\
\hline RS x SP & & $4.9284^{\mathrm{ns}}$ & \\
\hline Error & & 3.9645 & \\
\hline
\end{tabular}

** Significant at $1 \%$ probability by the $\mathrm{F}$ test. ${ }^{\mathrm{ns}}$ not significant at $5 \%$ probability by the $\mathrm{F}$ test.

Means followed by the same lowercase letter in the column and uppercase letter in the row do not differ by Tukey test, at 5\% probability.

In the spacing of 6 and $9 \mathrm{~cm}$ between plants, there was no difference in the non-commercial root yield concerning the row spacings of 10,15 , and $20 \mathrm{~cm}$. The lowest non-commercial root yield was found in the spacing of $20 \mathrm{~cm}$ between rows and $3 \mathrm{~cm}$ between plants, due to the lowest non-damaged root yield in the row spacing of $20 \mathrm{~cm}$ (Table 3 ).

It was observed that in the row spacing of 10,15 , and $20 \mathrm{~cm}$, the spacing between plants of $3 \mathrm{~cm}$ had the highest non-commercial root yield (Table 5), with values of 10.66; 11.03 and 6.34 t ha-1, respectively.

Given the results observed in the present study and due to the prospects of increasing radish production in Uruçuí-PI, such information is essential for producers to maximize the use of their areas, with a higher financial return and less waste with non-commercial roots.

\section{Conclusions}

The row spacing did not influence the development of the plants, but it affected the root yield. The row spacing of $20 \mathrm{~cm}$ had the lowest root yield.
The spacings that provided the highest commercial root yield (D> $30 \mathrm{~mm}$ ) of the Margaret Queen radish hybrid were 10 and $15 \mathrm{~cm}$ between rows and $6 \mathrm{~cm}$ between plants.

The $3 \mathrm{~cm}$ spacing between plants is the least suitable for the cultivation of the Margaret Queen radish hybrid radish under the studied conditions.

\section{Bibliographic References}

Amorim, M.S., Almeida, D.J.S., Silva, M.A.M., Silva, B.S., Freitas, A.F.J., 2014. Qual é o espaçamento ideal para maximizar a produção de rabanete. Enciclopédia Biosfera, 10(19), 1573-1579.

Aquino, L.A., Puiatti, M., Pereira, P.R.G., Pereira, F.H.F., Castro, M.R.S., Ladeira, I.R., 2005. Características produtivas do repolho em função de espaçamentos e doses de nitrogênio. Horticultura Brasileira, 23(2), 266-270.

Baier, J.E., Resende, J.T.V., Galvão, A.G., Battistelli, G.M., Machado, M.M., Faria, M.V., 2009. Produtividade e rendimento comercial de bulbos de cebola em função da densidade de cultivo. Ciência Agrotécnica, 33(2), 496-501. 
Bonela, G.D., Santos, W.P.S., Sobrinho, E.S., Gomes, E.J.C., 2017. Produtividade e qualidade de raízes de rabanete cultivadas sob diferentes fontes residuais de matéria orgânica. Revista Brasileira de Agropecuária Sustentável, 7(2), 66-74.

Camargo, G.A., Consoli, L., Lellis, I.C.S., Mieli, J., Sassaki, E.K., 2007. Bebidas naturais de frutas perspectivas de mercado, componentes funcionais e nutricionais. Revista Brasileira de Engenharia de Biossistemas, 1(2), 181-195.

Castro, B.F., Santos, L.G., Brito, C.F.B., Fonseca, V.A., Bebé, F.V., 2016. Produção de rabanete em função da adubação potássica e com diferentes fontes de nitrogênio. Revista Ciências Agrárias, 39(3), 341-348.

Corrêa, C.V., Cardoso, A.I.I., Souza, L.G., Antunes, W.L.P., Magolbo, L.A., 2014. Produção de beterraba em função do espaçamento. Horticultura Brasileira, 32(1), 111-114.

Costa, C.C., Oliveira, C.D., Silva, C.J., Timossi, P.C., Leite, I.C., 2006. Crescimento, produtividade e qualidade de raízes de rabanete cultivadas sob diferentes fontes e doses de adubos orgânicos. Horticultura Brasileira, 24(1), 118-122.

Ferreira, D.F., 2010. Sisvar, versão 5.6 (Build 86). DEX/UFLA.

Freitas, K.K.C., Bezerra Neto, F., Grangeiro, L.C., Lima, J.S.S., Moura, K.H.S., 2009. Desempenho agronômico de rúcula sob diferentes espaçamentos e épocas de plantio. Revista Ciência Agronômica, 40(3), 449-454.

INMET, 2018. Instituto meteorológico de pesquisa. http://www.inmet.gov.br/projetos/rede/pesquisa/gera_serie_txt _mensal.php?\&mRelEstacao $=82578 \&$ btnProcesso $=$ serie $\& \mathrm{mR}$ elDtInicio $=01 / 07 / 2014 \& \mathrm{mRelDtFim}=01 / 11 / 1014 \& \mathrm{mAtributos}$ $=,,,,,,, 1,,, 1,, 1,1$, (acessado 01 de setembro de 2018).

Janick, J.V., 1986. A ciência da horticultura. Freitas Bastos, São Paulo.

Lemos Neto, H.S., Maia, C.L., Costa, M.R., Rabelo, J.S., Hendges, A.R.A., Guimarães, M.A., 2018. Fisiologia do rabaneteiro em diferentes arranjos espaciais. Revista de Ciências Agrarias, 61, 1-6.

Linhares, P.C.F., Pereira, M.F.S., Oliveira, B.S., Henriques, G.P.S.A., Maracajá, P.B., 2010. Produtividade de rabanete em sistema orgânico de produção. Revista Verde de Agroecologia e Desenvolvimento Sustentável, 5(5), 94-101.
Lopes, W.A.R., Negreiros, M.Z., Teófilo, T.M.S., Alves, S.S.V., Martins, C.M., Nunes, G.H.S., Grangeiro, L.C., 2008. Produtividade de cultivares de cenoura sob diferentes densidades de plantio. Revista Ceres, 55(5), 482-487.

Maia, P.M.E., Aroucha, E.M.M., Silva, O.M.P., Silva, R.C.P., Oliveira, F.A., 2011. Desenvolvimento e qualidade do rabanete sob diferentes fontes de potássio. Revista Verde de Agroecologia e Desenvolvimento Sustentável, 6(1), 148-153.

Minami, K., Cardoso, A.I.I., Costa, F., Duarte, F.R., 1998. Efeito do espaçamento sobre a produção em rabanete. Bragantia, 57(1), 169-173.

Moreira, R.S., Santos, M.R., Sousa, R.A., Almeida, R.S., Gomes Junior, F.A., Coelho, W.A.A., 2019. Agronomic performance and yield of radish cultivars. Revista de Agricultura Neotropical, 6(3), 6-11.

Resende, G.M., Costa, N.D., 2003. Características produtivas da melancia em diferentes espaçamentos de plantio. Horticultura Brasileira, 21(4), 695-698.

Salgado, A.S., Guerra, J.G.M., Almeida, D.L., Ribeiro, R.L.D., Espinola, J.A.A., Salgado, J.A.A., 2006. Consórcios alfacecenoura e alface rabanete sob manejo orgânico. Pesquisa Agropecuária Brasileira, 41(7), 1141-1147.

Silva, L.F.O., Campos, K.A., Morais, A.R., Cogo, F.D., Zambon, C.R., 2012. Tamanho ótimo de parcela para experimentos com rabanete. Revista Ceres, 59(5), 624-629.

Steiner, F., Pinto Junior, A.S., Zoz, T., Guimarães, V.F., Dranski, J.A.L., Rheinheimer, A.R., 2009. Germinação de sementes de rabanete sob temperaturas adversas. Revista Brasileira de Ciências Agrárias, 4(4), 430-434.

Vidigal, S.M., Pedrosa, M.W., 2007. Rabanete, in: Paula Júnior, T.J., Venzon, M., (Ed.). 101 Culturas: Manual de tecnologias agrícolas. EPAMIG, Belo Horizonte, p. 661-664.

Vidigal, S.M., Pedrosa, M.W., 2019. Rabanete, in: Paula Júnior, T.J., Venzon, M., (Ed.). 101 Culturas: Manual de tecnologias agrícolas, segunda ed. EPAMIG, Belo Horizonte, p. 795-798.

Weston, G., 1982. The effects of crowding, daminazide and red to far-red ratios of light on the growth of radish (Raphanus sativus L.). Journal of Horticultural Science, 57(3), 373-376. 